\title{
ANTIMICROBIAL AND ANTILEISHMANIAL ACTIVITY OF ESSENTIAL OIL FROM THE LEAVES OF Annona foetida (ANNONACEAE)
}

\author{
Emmanoel Vilaça Costa, Maria Lúcia Belém Pinheiro* e Jefferson Rocha de Andrade Silva \\ Departamento de Química, Universidade Federal do Amazonas, Av. Gal. Rodrigo Otávio Jordão Ramos, 3000, 69077-000 \\ Manaus - AM, Brasil \\ Beatriz Helena Lameiro de Noronha Sales Maia \\ Departamento de Química, Universidade Federal do Paraná, CP 19081, 81531-990 Curitiba - PR, Brasil \\ Marta Cristina Teixeira Duarte \\ Centro Pluridisciplinar de Pesquisas Químicas, Biológicas e Agrícolas, Universidade Estadual de Campinas, 13140-000 \\ Campinas - SP, Brasil \\ Ana Cláudia Fernandes Amaral \\ Departamento de Produtos Naturais, Farmanguinhos/FIOCRUZ, Rua Sizenando Nabuco, 100, 21041-250 Rio de Janeiro - RJ, \\ Brasil \\ Gérzia Maria de Carvalho Machado e Leonor Laura Leon \\ Departamento de Imunologia, Instituto Oswaldo Cruz/FIOCRUZ, Av. Brasil, 4365, 21045-900 Rio de Janeiro - RJ, Brasil
}

Recebido em 2/1/08; aceito em 6/8/08; publicado na web em 15/12/08

\begin{abstract}
The essential oil from leaves of Annona foetida obtained by hydrodistillation was analyzed by GC/FID and GC/MS. The results showed that the major constituents were bicyclogermacrene (35.12\%), (E)-caryophyllene (14.19\%) and $\alpha$-copaene (8.19\%). The antimicrobial and antileishmanial activities were investigated. The oil showed potent antimicrobial activity against Candida albicans and Rhodococcus equi. The oil also showed significant antileishmanial activity, giving the best results against Leishmania guyanensis. A preliminary cytotoxicity assay for this oil was carried out on hamster and mice (Balb/c) peritoneal macrophages. The results obtained were similar to pentamidine and considered not to be cytotoxic to macrophages.
\end{abstract}

Keywords: Annona foetida; antimicrobial and antileishmanial activities; essential oil composition.

\section{INTRODUCTION}

The Annonaceae is a large family of tropical and subtropical trees and shrubs, comprising about 135 genera and more than 2500 species. $^{1}$ This family is known for the edible fruits ${ }^{2}$ and medicinal properties of many species. ${ }^{3}$ Previous chemical and pharmacological investigations on some species of this family have indicated the presence of important bioactive compounds, exhibiting various pharmacological activities including antimicrobial, ${ }^{4,5}$ insecticidal ${ }^{4,5}$ and antiparasitic properties, in particular against Leishmania sp. ${ }^{6-10}$ Plasmodium falciparum ${ }^{11,12}$ and Trypanosoma cruzi. ${ }^{7,8,10}$ These activities are attributed to aporphine ${ }^{4,8}$ and $\beta$-carboline ${ }^{6}$ alkaloids, lactones, ${ }^{9}$ acetogenins ${ }^{10}$ and essential oils. ${ }^{12}$ Among several species of Annonaceae with antiparasitic activity is Annona foetida Martius. This species, commonly known as "araticum caatinga", "envira-ata" or "graviola do mato," is a tropical tree found in the Brazilian and Peruvian Amazon region. ${ }^{3,13}$ Besides the antileishmanial activity demonstrated by the extracts, fractions and pure compounds isolated from this source, ${ }^{6}$ this species is also reportedly used in folk medicine in the Brazilian northeast against rheumatism, intermittent fevers and ulcers, particularly the leaves and the bark. ${ }^{3}$

In previous studies on this species, aporphine and $\beta$-carboline alkaloids with antileishmanial activity were isolated. ${ }^{6}$ In continuation of our studies on A. foetida in a search for novel antileishmanial and antimicrobial natural products, we now report the characterization of the essential oil from the leaves. This is the first report on the analysis of the volatile constituents from leaves of this plant and their biological activity.

*e-mail: 1belem@ufam.edu.br

\section{EXPERIMENTAL}

\section{Plant material}

The leaves of $A$. foetida were collected at the Adolpho Ducke Reserve [coordinates: $02^{\circ} 57^{\prime} 21^{\prime \prime} \mathrm{S} 59^{\circ} 55^{\prime} 20^{\prime}$ 'W], near the city of Manaus, Amazonas, Brazil. The plant was identified by the Annonaceae specialist Dr. A. C. Webber from the Universidade Federal do Amazonas (UFAM). A voucher specimen (number 7275) is deposited at the Herbarium of UFAM, Manaus, Amazonas, Brazil.

\section{Extraction of essential oil}

The leaves ( $200 \mathrm{~g}$ ) of A. foetida were dried at room temperature for 3 days and submitted to hydrodistillation for $4 \mathrm{~h}$, in a Clevengertype apparatus. The oil was dried over anhydrous sodium sulphate, and the percentage content was calculated on the basis of the dry weight of plant material. The oil was stored at $4{ }^{\circ} \mathrm{C}$ for further analysis. The extraction of essential oil was performed in triplicate.

\section{Chemical analyses}

\section{GC/FID}

The analyses of the volatile compounds were carried out on a Varian $3800 \mathrm{GC}$ system with a fused capillary column (30 m x 0.25 mm x $0.25 \mu \mathrm{m}$, VA-5 Crossbond 5\% phenyl-95\% dimethylpolysiloxane, Sigma-Aldrich) directly coupled to a flame ionization detector. Conditions of injection were modified from Adams: ${ }^{14}$ injector tem- 
perature $240{ }^{\circ} \mathrm{C}$; oven temperature program of $60-300{ }^{\circ} \mathrm{C}$ at a rate of $3{ }^{\circ} \mathrm{C} / \mathrm{min}$; split 20:1 during $1.50 \mathrm{~min}$, carrier gas He: $1.0 \mathrm{~mL} \mathrm{~min}{ }^{-1}$, constant flow; sample volume $1 \mu \mathrm{L}$.

\section{GC/MS}

The analyses were performed using the EI mode on a Varian 3800 GC system with a fused capillary column $(30 \mathrm{~m} \times 0.25 \mathrm{~mm} \times 0.25$ mm, VF-5MS, Crossbond 5\% phenyl - 95\% dimethylpolysiloxane) directly coupled to a Varian Saturn 2000 selective mass detector. The conditions of injection were the same as described above. The mass spectrometer was operated at $70 \mathrm{eV}$. Retention indices (RI) were determined by co-injection of hydrocarbon standards. ${ }^{15}$ The oil components were identified by comparison with data from the literature ${ }^{14}$ and the profiles from the NIST-05 library.

\section{Antimicrobial assay}

The growth inhibitory activity of the essential oil was tested against 11 microorganisms (Bacillus subtilis ATCC 5061, Candida albicans ATCC 10231, Enterococcus faecium CCT 5079, Enterococcus hirae ATCC 10541, Escherichia coli ATCC 11775, Micrococcus luteus ATCC 4698, Pseudomonas aeruginosa ATCC 13388, Rhodococcus equi ATCC 6939, Salmonella choleraesuis ATCC 10708, Staphylococcus aureus ATCC 6538 and Staphylococcus epidermides ATCC 12228).

The bacteria strains were cultured overnight at $36^{\circ} \mathrm{C}$ in Nutrient Agar (Merck), while C. albicans was cultured in Saboraud Dextrose Agar. Inoculum for the assays was prepared by diluting a scraped cell mass in $0.85 \% \mathrm{NaCl}$ solution, adjusted to McFarland scale 0.5 and confirmed by spectrophotometer reading at $580 \mathrm{~nm}$. Cell suspensions

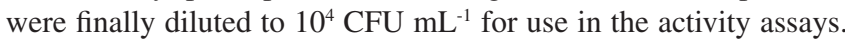
MIC (Minimal Inhibitory Concentration) tests were carried out according to Eloff, ${ }^{16}$ using Müller-Hinton broth on a tissue-culture test plate (96 wells). The stock solution of essential oil was diluted and transferred into the first well, and serial dilutions were made so that concentrations in the range of $1.0-0.015 \mathrm{mg} \mathrm{mL}^{-1}$ were obtained. Chloramphenicol and nystatin (Merck) were used as the reference antibiotic control in the range of $0.25-0.002 \mathrm{mg} \mathrm{mL}^{-1}$. The inoculum was added to all wells, and the plates were incubated at $36^{\circ} \mathrm{C}$ for $48 \mathrm{~h}$. Each concentration was screened in triplicate. Antimicrobial activity was detected by adding $20 \mu \mathrm{L}$ of $0.5 \%$ TTC (triphenyl tetrazolium chloride, Merck) aqueous solution. MIC was defined as the lowest concentration of the essential oil that inhibited visible growth, as indicated by TCC staining (dead cells are not stained by TTC).

\section{In vitro antileishmanial assay}

Cultures of Leishmania amazonensis (MHOM/BR/77/LTB0016), L. braziliensis (MHOM/BR/95/IOCL-2033), L. chagasi (MCAN/ BR/97/P142) and L. guyanensis (MHOM/BR/95/IOCL-2092) promastigotes characterized by isoenzyme analysis were used for in vitro screening. Briefly, promastigotes were cultivated in Schneider's Drosophila medium supplemented with $20 \%$ (v/v) heat-inactivated fetal calf serum (FCS) and harvested from the medium in the latelog phase. The antileishmanial screening of the essential oil was performed in flat-bottomed plastic 96-well tissue plates maintained at $26^{\circ} \mathrm{C}$. Promastigote forms were suspended to yield $4.0 \times 10^{6}$ cells $\mathrm{mL}^{-1}$ after hemocytometer counting. Each well was filled with 100 $\mu \mathrm{L}$ of the parasite suspension, and the plates were incubated at 26 ${ }^{\circ} \mathrm{C}$. The essential oil to be tested was dissolved in DMSO and then added to each well to obtain a final concentration of $0.16 \mu \mathrm{g} \mathrm{mL} \mathrm{L}^{-1}$. At up to $1.6 \%(\mathrm{v} / \mathrm{v})$, DMSO had no effect on parasite growth. Each concentration range $160-0.16 \mu \mathrm{g} \mathrm{mL}^{-1}$ was screened in triplicate. The oil and pentamidine isethionate (reference drug) were added to the culture, and after $24 \mathrm{~h}$ the viability of the treated cells was compared to the control without drugs, through the MTT methodology. ${ }^{17,18}$

\section{Cytotoxicity assay}

In order to evaluate the toxicity of the compound to the host cell, mice or hamster peritoneal macrophages were isolated in RPMI 1640 medium (Sigma Cell Culture, St. Louis, Missouri, USA), containing $200 \mathrm{UI} \mathrm{mL} \mathrm{m}^{-1}$ penicillin, $200 \mu \mathrm{g} \mathrm{mL}^{-1}$ streptomycin, $1 \mathrm{mM}$ sodium pyruvate, $1 \mathrm{mM}$ L-glutamine and $1 \mathrm{M}$ HEPES buffer (Sigma Cell Culture, St. Louis, Missouri, USA). Cells were counted in a Neubauer chamber using Erythrosine B as a vital dye (Sigma Cell Culture, St. Louis, Missouri, USA), and adjusted to a concentration of $4.0 \times 10^{6}$ cell $\mathrm{mL}^{-1}$. After that, cells were cultured in a 96-well culture plate (Falcon, New Jersey, USA), at $37^{\circ} \mathrm{C}$ and in an atmosphere of $5 \% \mathrm{CO}_{2}$ The sample was added to the medium in a concentration equivalent to $\mathrm{IC}_{50}$ and $2 \mathrm{x} \mathrm{CC}_{50}$ of the in-vitro activity assay from L. amazonensis and $L$. chagasi. The sample and pentamidine isethionate (reference drug) were added to the culture, and after $24 \mathrm{~h}$ the viability of treated cells was compared to the control without drugs, through the MTT methodology. ${ }^{17,18}$

\section{RESULTS AND DISCUSSION}

\section{Chemical study}

Hydrodistillation of the leaves of A. foetida gave a yellowish crude essential oil, with a yield of $0.01 \%$ in relation to the dry weight of the plant material, and a density at $25{ }^{\circ} \mathrm{C}$ of $0.9055 \mathrm{~g} \mathrm{~mL}^{-1}$. As shown in Table 1, 34 compounds of the essential oil were identified by GC/FID and GC/MS analysis, comprising $93.06 \%$ of the oil. The results of the analyses showed that the oil is a complex mixture, consisting particularly of sesquiterpenes. The major components identified were bicyclogermacrene $(35.12 \%),(E)$-caryophyllene (14.19\%), $\alpha$-copaene $(8.19 \%)$ and $\gamma$-cadinene $(4.84 \%)$. Other constituents identified in smaller quantities were viridiflorol (3.51\%), cis- $\beta$-guaiene (3.47\%), $\gamma$-muurolene (2.77\%), $\alpha$-humulene $(2.22 \%)$, aromadendrene $(1.81 \%), \alpha$-cubebene (1.60\%), allo-aromadendrene (1.51\%), spathulenol $(1.11 \%), \alpha$-gurjunene $(1.26 \%)$ and cyperene $(1.23 \%)$. Monoterpenes were not detected in the oil.

The presence of bicyclogermacrene, $(E)$-caryophyllene, $\gamma$-muurolene, $\alpha$-humulene, spathulenol and $\beta$-elemene and the other compounds identified in our study has been reported in essential oils of many species of the familyAnnonaceae. ${ }^{19-22}$ Among these identified components, the oxygenated sesquiterpene spathulenol is considered as a chemotaxonomic marker of species of Annonaceae, because it has been identified in several species of this family belonging to the genera Annona, Artabotrys, Cleistopholis, Desmos, Duguetia, Fusae, Goniothalamus, Guatteria, Guatteriopsis, Hexalobus, Melodorum, Pachypodanthium, Piptostigma, Uvaria and Xylopia. ${ }^{12,19-22}$ (E)caryophyllene is frequently found in the species of Annona, and could be considered together with caryophyllene oxide as chemotaxonomic markers for this genus. ${ }^{12,19-22}$

\section{Antimicrobial activity}

The results obtained in the evaluation of the antimicrobial activity of the essential oil of A. foetida are shown in Table 2. The essential oil of $A$. foetida exhibited a significant antimicrobial activity against 5 of the 11 microorganisms tested, showing strong activity against Candida albicans and Rhodococcus equi, both with MIC values of 60 $\mu \mathrm{g} \mathrm{mL} \mathrm{L}^{-1}$. For Micrococcus luteus, Bacillus subtilis and Staphylococcus 
Table 1. Chemical composition of essential oil from the leaves of Annona foetida

\begin{tabular}{|c|c|c|c|}
\hline Constituents $^{\mathrm{a}}$ & $\mathrm{RI}^{\mathrm{b}}$ & $\mathrm{RI}^{\mathrm{c}}$ & $\%$ \\
\hline$\delta$-Elemene & 1331 & 1338 & 0.27 \\
\hline$\alpha$-Cubebene & 1346 & 1351 & 1.60 \\
\hline Isoledene & 1369 & 1376 & 0.13 \\
\hline$\alpha$-Copaene & 1375 & 1377 & 8.19 \\
\hline$\beta$-Bourbonene & 1382 & 1388 & 0.50 \\
\hline$\beta$-Cubebene & 1387 & 1388 & 0.91 \\
\hline$\beta$-Elemene & 1389 & 1391 & 0.98 \\
\hline Cyperene & 1401 & 1399 & 1.23 \\
\hline$\alpha$-Gurjunene & 1409 & 1410 & 1.26 \\
\hline (E)-Caryophyllene & 1418 & 1419 & 14.19 \\
\hline$\beta$-Copaene & 1429 & 1432 & 0.55 \\
\hline$\beta$-Gurjunene & 1433 & 1434 & 0.21 \\
\hline Aromadendrene & 1437 & 1441 & 1.81 \\
\hline cis-Muurola-3,5-diene & 1448 & 1450 & 0.52 \\
\hline$\alpha$-Humulene & 1454 & 1455 & 2.22 \\
\hline Allo-Aromadendrene & 1458 & 1460 & 1.51 \\
\hline trans-Cadina-1(6),4-diene & 1472 & 1477 & 0.89 \\
\hline$\gamma$-Gurgenene & 1475 & 1477 & 1.04 \\
\hline$\gamma$-Muurolene & 1480 & 1480 & 2.77 \\
\hline$\delta$-Selinene & 1488 & 1493 & 0.42 \\
\hline cis- $\beta$-Guaiene & 1491 & 1493 & 3.47 \\
\hline Bicyclogermacrene & 1496 & 1500 & 35.12 \\
\hline$\alpha$-Muurolene & 1499 & 1500 & 0.21 \\
\hline trans- $\beta$-Guaiene & 1507 & 1503 & 0.22 \\
\hline$\beta$-Himachalene & 1513 & 1505 & 0.20 \\
\hline$\gamma$-Cadinene & 1518 & 1512 & 4.84 \\
\hline$\delta$-Cadinene & 1523 & 1523 & 0.80 \\
\hline$(E)$ - $\gamma$-Bisabolene & 1528 & 1531 & 0.14 \\
\hline trans-Cadina-1(2),4-diene & 1533 & 1535 & 0.54 \\
\hline Germacrene B & 1558 & 1561 & 0.80 \\
\hline Spathulenol & 1579 & 1578 & 1.11 \\
\hline Viridiflorol & 1595 & 1593 & 3.51 \\
\hline 1-epi-Cubenol & 1630 & 1629 & 0.46 \\
\hline Cubenol & 1645 & 1647 & 0.44 \\
\hline Compounds identified & & & 93.06 \\
\hline Compounds not identified & & & 6.94 \\
\hline Total & & & 100 \\
\hline
\end{tabular}

${ }^{a}$ Identification was based on comparison of their GC/MS spectra and RI with those of the internal (computer) NIST library and those described by Adams $(2001)^{14}$. ${ }^{\mathrm{b}}$ RI was determined on VF-5MS on the basis of n-alkanes, and calculated according to the method of Van Den Dool and Kratz (1963). ${ }^{15}$ c RI according to ref. 14

aureus, the essential oil showed activity with MIC values of 200, 600 and $200 \mu \mathrm{g} \mathrm{mL}^{-1}$, respectively. The results obtained for the essential oil against $C$. albicans and $R$. equi were close to the results shown by the reference drugs, indicating that this oil is a natural source of biologically active compounds. The results observed against $R$. equi, a bacterium responsible for pneumonia in animals, are very promising,
Table 2. MIC values for essential oil from leaves of Annona foetida

\begin{tabular}{lcc}
\hline & \multicolumn{2}{c}{ MIC $\left.(\mu \mathrm{g} \mathrm{mL})^{-1}\right)$} \\
Microorganism & Essential & Reference \\
& Oil & Drug \\
\hline Bacillus subtilis ATCC 5061 & 600 & $20^{\mathrm{a}}$ \\
Candida albicans ATCC 10231 & 60 & $50^{\mathrm{b}}$ \\
Enterococcus faecium CCT 5079 & - & $70^{\mathrm{a}}$ \\
Enterococcus hirae ATCC 10541 & - & $120^{\mathrm{a}}$ \\
Escherichia coli ATCC 11775 & - & $40^{\mathrm{a}}$ \\
Micrococcus luteus ATCC 4698 & 200 & $50^{\mathrm{a}}$ \\
Pseudomonas aeruginosa ATCC 13388 & - & $850^{\mathrm{a}}$ \\
Rhodococcus equi ATCC 6939 & 60 & $40^{\mathrm{a}}$ \\
Salmonella choleraesuis ATCC 10708 & - & $60^{\mathrm{a}}$ \\
Staphylococcus aureus ATCC 6538 & 200 & $20^{\mathrm{a}}$ \\
Staphylococcus epidermides ATCC 12228 & - & $40^{\mathrm{a}}$ \\
\hline
\end{tabular}

$(-)>1000 \mu \mathrm{g} \mathrm{mL}{ }^{-1} .{ }^{\text {a }}$ Chloramphenicol. ${ }^{\mathrm{b}}$ Nystatin. ATCC (American Type Culture Collection). CCT (Tropical Culture Collection)

particularly for veterinary medicine. In Brazil this infection is one of the most severe diseases affecting colts and other young animals, causing high mortality even if the animals are treated with antimicrobial agents. ${ }^{23}$ This is the second report of medicinal plants belonging to Annonaceae that show antimicrobial activity against $R$. equi. ${ }^{22}$

The significant antimicrobial activity of the essential oil from leaves of A. foetida may be attributed to the high sesquiterpene content (93.05\%), along with minor terpenoid constituents. The co-occurrence of bicyclogermacrene and $(E)$-caryophyllene has been reported in antimicrobial essential oils $\mathrm{s}^{24,25}$ and this activity is largely shown by essential oils containing $(E)$-caryophyllene. ${ }^{26,27}$

\section{Antileishmanial activity}

The results of the evaluation of antileishmanial activity of the essential oil of A. foetida are shown in Table 3. This essential oil was active against all species of Leishmania tested. The best result was observed against L. guyanensis, with $\mathrm{IC}_{50}$ value of $4.1 \mu \mathrm{g} \mathrm{mL}^{-1}$. The results obtained against $L$. braziliensis, L. amazonensis and $L$. chagasi were, respectively, 9.9, 16.2 and $27.2 \mu \mathrm{g} \mathrm{mL}^{-1}, \mathrm{IC}_{50}$ values.

The observed antileishmanial activity can probably be attributed to the mixture of sesquiterpene constituents, as observed for the antimicrobial activity. Several oxygenated sesquiterpenes have evidenced significant activity against Leishmania sp. ${ }^{28,29}$ but there is no scientific report on antileishmanial activity for unfunctionalized sesquiterpenes, and the mechanisms of action remain unclear. Recent studies on cultures of L. amazonensis promastigotes revealed that

Table 3. In vitro activity of essential oil of Annona foetida against species of Leishmania (promastigote forms)

$$
\mathrm{IC}_{50}\left(\mu \mathrm{g} \mathrm{mL} \mathrm{m}^{-1}\right)
$$

\begin{tabular}{lcccc} 
Sample & $\begin{array}{c}\text { L. amazon- } \\
\text { ensis }\end{array}$ & $\begin{array}{c}\text { L. brazilien- } \\
\text { sis }\end{array}$ & L. chagasi & $\begin{array}{c}\text { L. guyan- } \\
\text { ensis }\end{array}$ \\
\hline $\begin{array}{l}\text { Essential Oil } \\
16.2 \pm 1.9\end{array}$ & $9.9 \pm 1.2$ & $27.2 \pm 6.2$ & $4.1 \pm 0.2$ \\
$\begin{array}{l}\text { Pentami- } \\
\text { dine }^{\text {a }}\end{array}$ & $4.8 \pm 0.1$ & $1.0 \pm 0.1$ & $19.0 \pm 2.9$ & $0.3 \pm 0.1$ \\
\hline
\end{tabular}

${ }^{a}$ Reference drug. 
the oxygenated sesquiterpene nerolidol possesses antileishmanial activity, which may be associated with inhibition of the biosynthesis of cellular isoprenoids. ${ }^{30}$ This encourages an intensive investigation of the mechanisms of action of terpene essential oils.

It has been also suggested that the low density of the essential oils and their ready diffusion across cell membranes contribute to enhance targeting intracellular protozoal malaria parasites. ${ }^{12}$ Nevertheless, further studies are required to explain the complete mechanisms of these interactions, particularly in the specific case of leishmaniasis.

The oil was also tested for cytotoxicity, using hamster and mice (Balb/c) peritoneal macrophages (unparasitized cells), considering that the former is the animal model for L. chagasi, and the latter is the animal model for L. amazonensis (Table 4). The oil showed a low cytotoxicity to hamster peritoneal macrophages (less than 6\%), while the reference drug pentamidine isethionate did not show any cytotoxicity. For Balb/c macrophages, the sample and the reference drug showed similarly low cytoxicity (less than 6\%) and can be considered as not cytotoxic.

Table 4. In vitro cytotoxicity assay of essential oil of Annona foetida using hamster and mice peritoneal macrophage (Balb/c) cells in 24 $\mathrm{h}(\%)$

\begin{tabular}{lcc}
\hline \multirow{2}{*}{ Sample $\left(\mu \mathrm{g} \mathrm{mL}^{-1}\right)$} & \multicolumn{2}{c}{ Cytotoxicity $(\%)$} \\
& Hamster cells & Mice $(\mathrm{Balb} / \mathrm{c})$ cells \\
\hline Essential Oil $\left(\mathrm{IC}_{50}\right)$ & 3.17 & 5.67 \\
Essential Oil $\left(2 \mathrm{x} \mathrm{IC}_{50}\right)$ & 4.76 & 7.26 \\
Pentamidine $^{\mathrm{a}}$ & 0.00 & 5.47 \\
\hline
\end{tabular}

${ }^{a}$ Reference drug.

\section{CONCLUSION}

This is the first report on the analysis of the volatile constituents from leaves of $A$. foetida and its biological activities. The essential oil demonstrated significant antimicrobial and antileishmanial activities, and low cytotoxicity to hamster and mice $(\mathrm{Balb} / \mathrm{c})$ peritoneal macrophages, suggesting that this species is a rich source of biologically active compounds. The presence of spathulenol in this oil is very important for the chemotaxonomy of the family Annonaceae, because it has been found in almost all the genera of this family, particularly in Annona, Guatteria and Xylopia. The results obtained in this study confirm the importance of chemical and biological investigations of essential oils of annonaceous species in the search for new and safer antimicrobial and antileishmanial agents.

\section{ACKNOWLEDGEMENTS}

The authors thank Prof. Dr. A. C. Webber (UFAM) for the botanical identification of the plant material, and Prof. Dr. F. A. Marques and MSc. K. Nicollini (UFPR) for the GC analyses. This study was supported by CAPES/RENOR and CNPq/PADCT.

\section{REFERENCES}

1. Chatrou L. W.; Rainer H.; Maas P. J. M. In Annonaceae (Soursop Family); Smith, N.; Mori, S. A.; Henderson, A.; Stevenson, D. W.; Heald, S V., eds.; Princeton University Press: New Jersey, 2004, p. 18-20.

2. Kessler, P. J. A. In Annonaceae; Kubitski, K., Rohwer, J. C.; Bittrich, V., eds.; Springer-Verlag, Berlin, 1993, vol. 2, p. 93-129.
3. Corrêa, M. P.; Dicionário das plantas úteis do Brasil, Ministério da Agricultura, Instituto Brasileiro de Desenvolvimento Florestal, 1984, vol. 1, p.154.

4. Khan, M. R.; Kihara, M.; Omoloso, A. D.; Fitoterapia 2002, 73, 744.

5. Rahman, M. M.; Lopa, S. S.; Sadik, G.; Islam, R.; Khondkar, P.; Alam, A. H. M. K.; Rashid, M. A.; Fitoterapia 2005, 76, 758.

6. Costa, E. V.; Pinheiro, M. L. B.; Xavier, C. M.; Silva, J. R. A.; Amaral, A. C. F.; Souza, A. D. L.; Barison, A.; Campos, F. R.; Ferreira, A. G.; Machado, G. M. C.; Leon, L. L. P. J.; J. Nat. Prod. 2006, 69, 292.

7. Queiroz, E. F.; Roblot, F.; Cavé, A.; Paulo, M. Q.; Fournet, A.; J. Nat. Prod. 1996, 59, 438.

8. Montenegro, H.; Gutiérrez, M.; Romero, L. I.; Ortega-Barria, E.; Capson, T. L.; Rios, L. C.; Planta Med. 2003, 69, 677.

9. Akendengue, B.; Roblot, F.; Loiseau, P. M.; Bories, C.; Ngou-Milama, E.; Laurens, A.; Hocquemiller, R.; Phytochemistry 2002, 59, 885.

10. Sahpaz, S.; Bories, C.; Loiseau, P. M.; Cortès, D.; Hocquemiller, R.; Laurens, A.; Cavé, A.; Planta Med. 1994, 60, 538.

11. Nkunya, M. H. H.; Waibel, R.; Achenback, H.; Phytochemistry 1993, 34,853 .

12. Boyom, F. F.; Ngouana, V.; Zollo, P. H. A.; Menut, C.; Bessiere, J. M.; Gut, J.; Rosenthal, P. J.; Phytochemistry 2003, 64, 1269.

13. Ribeiro, J. E. L. S.; Maas, P. J. M.; Maas, H.; Miralha, J. M.; Webber, A. In Annonaceae; Ribeiro, J. E. L. S.; Hopkins, M. J. G.; Vicentini, A.; Sothers, C. A.; Costa, M. A. S.; Brito, J. M.; Souza, M. A. D.; Martins, L. H. P.; Lohmann, L. G.; Assunção, P. A. C. L.; Pereira, E. C.; Silva, C. F.; Mesquita, M. R.; Procópio, L. C., eds.; INPA: Manaus, 1999, p. 121-135.

14. Adams, R. P.; Identification of Essential Oil Components by Gas Chromatography/Quadrupole Mass Spectroscopy, Allured Publishing Corporation: Carol Stream, 2001.

15. Van den Dool, H.; Kratz, P. D.; J. Chromatogr. 1963, 11, 463.

16. Ellof, J. N.; Planta Med. 1998, 64, 711.

17. Mosmann, T.; J. Immunol. Methods 1983, 65, 55.

18. Ferrari, M.; Fornasiero, M. C.; Isetta, A. M.; J. Immunol. Methods 1990, 131,165 .

19. Leboeuf, M.; Cave, A.; Bhaumik, P. K.; Mukherjee, B.; Mukherjee, R.; Phytochemistry 1982, 21, 2783.

20. Lima, M. A.; Barbosa-Filho, J. M.; Merlic, C. A.; Doroh, B. C.; Maia, J. G. S.; Silva, M. S.; Cunha, E. V. L.; Biochem. Syst. Ecol. 2004, 32, 347.

21. Maia, J. G. S.; Andrade, E. H. A.; Carreira, L. M. M.; Oliveira, J.; Araújo, J. S.; Flavour Frag. J. 2005, 20, 478.

22. Costa, E. V.; Teixeira, S. D.; Marques, F. A.; Duarte, M. C. T.; Delarmelina, C.; Pinheiro, M. L. B.; Trigo, J. R.; Maia, B. H. L. N. S.; Phytochemistry 2008, 69,1895.

23. Oliveira, G. F. X.; Neves, D. R.; Pedrosa, H. A.-S. R.; Viana, A. R.; Rev. Min. Saúde Púb. 2004, 5, 43.

24. Tabanca, N.; Demirci, F.; Ozek, T.; Tumen, G.; Baser, K. H. C.; Chem. Nat. Compd. 2001, 37, 238.

25. Farkas, P.; Hollá, M.; Tekel, J.; Mellen, S.; Vaverková, S.; Flavour Frag. J. 2005, 21, 186.

26. Chinou, I. B.; Roussis, V.; Perdetzoglou, D.; Tizakouk A.; Loukis, A.; Planta Med. 1997, 63, 181.

27. Couladis, M.; Tanimanidis A.; Tzakou O.; Chinou, B. I.; Harvala, C.; Planta Med. 2000, 66, 670.

28. Chan-Bacab, M. J.; Pena-Rodriguez, L. M.; Nat. Prod. Rep. 2001, 18 , 674.

29. Rocha, L. G.; Almeida, J. R. G. S.; Macêdo, R. O.; Barbosa-Filho, J. M.; Phytomedicine 2005, 12, 514.

30. Arruda, D. C.; D'Alexandri, F. L.; Katzin, A. M.; Uliana, S. R. B.; Antimicrob. Agents Chemother. 2005, 49, 1679. 